\title{
Some New Trinuclear Vanillin Schiff Base Complexes of Cobalt, Nickel and Copper
}

\section{Issam J. Sallomi \\ Wijdan A. Al-Zeadan}

Department of Chemistry / College of Education University of Mosul / Iraq

\section{Received}

24 / 05 / 2010

\section{Accepted}

$06 / 10 / 2010$

الخلاصة

أجرينا في هذا البحث تحضير بعض المعقدات ثلاثية النواة المتجانسة وغير المتجانسة للكوبلت والنيكل والنحاس وذلك بمفاعلة كلوريدات او نترات هذه الفلزات مع ليكاند من نوع قاعدة شيف مشتق من الفانلين والمالونيل هيدرازيد ـ لقد تم الحصول على معقدات بالصيغ العامة : g $\left.\left[\mathrm{M}_{3}\left(\mathrm{VMH}_{4}\right)_{2} \mathrm{X}_{6}\right)\right],\left[\mathrm{M}_{2} \mathrm{M}^{\prime}\left(\mathrm{VMH}_{4}\right)_{2} \mathrm{X}_{6}\right],\left[\mathrm{MM}^{\prime} \mathrm{M}^{\prime \prime}\left(\mathrm{VMH}_{4}\right)_{2} \mathrm{X}_{6}\right]$ اذ يمنل كل من: $\mathrm{K}_{2}\left[\mathrm{M} 3(\mathrm{VM})_{2}\right], \mathrm{K}_{2}\left[\mathrm{M}_{2} \mathrm{M}^{\prime}(\mathrm{VM})_{2}\right], \mathrm{K}_{2}\left[\mathrm{MM}^{\prime} \mathrm{M}^{\prime \prime}(\mathrm{VM})_{2}\right]$

ايونات الكوبلت والنيكل والنحاس الثنائي الموجب و لM, M,'M", المتعادل ورباعي القاعدة لليكاند و X ايون الكلوريد او النترات. تم تتخيص الليكاند ومعقداته

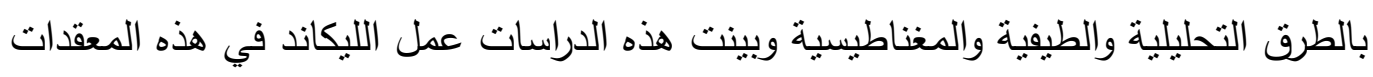
بشكل سداسي السن متعادل وسداسي السن رباعي القاعدة في كل من الوسطين المتعادل

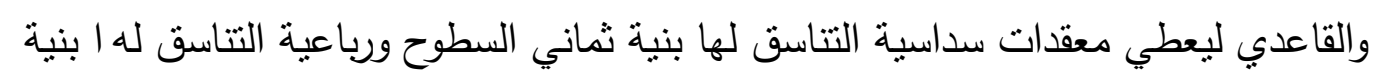

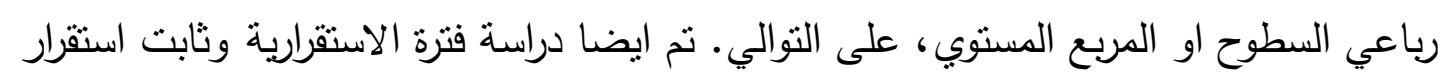
بعض من هذه المعقدات في المحلول المتعادل وذلك باستخدام طريقة قياس الأطياف الضوئية.

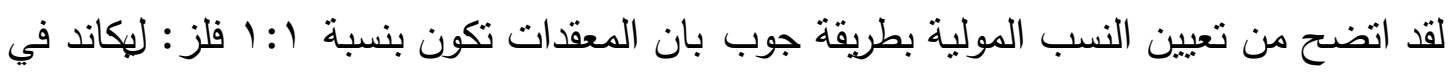

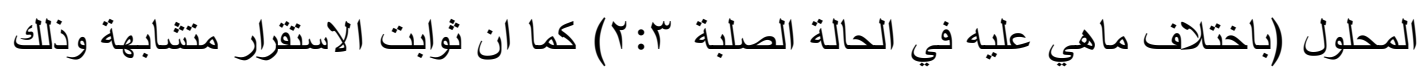
لكون العوامل المؤثرة منساوية.

\section{ABSTRACT}

In this study homo and hetero trinuclear complexes of cobalt (II), nickel (II) and copper (II) were prepared by the reaction of their salts (chloride and nitrate) with a Schiff base ligand derived from vanillin and 
malonylhydrazide. Complexes of the general formulae: $\left.\left[\mathrm{M}_{3}\left(\mathrm{VMH}_{4}\right)_{2} \mathrm{X}_{6}\right)\right]$, $\left[\mathrm{M}_{2} \mathrm{M}^{\prime}\left(\mathrm{VMH}_{4}\right)_{2} \mathrm{X}_{6}\right], \quad\left[\mathrm{MM}^{\prime} \mathrm{M}^{\prime \prime}\left(\mathrm{VMH}_{4}\right) 2 \mathrm{X} 6\right]$ and $\mathrm{K} 2\left[\mathrm{M}_{3}(\mathrm{VM})_{2}\right]$, $\mathrm{K}_{2}\left[\mathrm{M}_{2} \mathrm{M}^{\prime}(\mathrm{VM})_{2}\right], \mathrm{K}_{2}\left[\mathrm{MM}^{\prime} \mathrm{M}^{\prime \prime}(\mathrm{VM})_{2}\right]$ (where $\mathrm{M}, \mathrm{M}^{\prime}, \mathrm{M}^{\prime \prime}$ are the dipositive ions of cobalt, nickel and copper, respectively, $\mathrm{VMH}_{4}, \mathrm{VM}$ are the neutral and tetra basic forms of the ligand and $\mathrm{X}=\mathrm{Cl}, \mathrm{NO}_{3}$ ) were isolated from both neutral and basic media, respectively. The ligand and its complexes were characterized by using analytical, physical and spectral methods. The studies revealed the hexadentate nature of the ligand which gave hexacoordinated and tetracoordinated metal complexes with the most probable octahedral and tetrahedral or square planar structures in neutral and basic media, respectively. The stability period and the stability constants of some of these complexes in neutral solution have been studied spectrophotometrically. The compositions of the complexes were determined by the use of Job method. The results indicate the formation of only 1:1 metal: ligand complexes with similar stability constants.

\section{INTRODUCTION}

The rational design and synthesis of polynuclear coordination complexes, aiming at understanding the structure and chemical factors that govern the exchange coupling between paramagnetic centers are of continuing interest in biology, chemistry and physics [1-3]. Particular interest has recently been focused on the development of super molecular structures created by hydrogen bonds as a new challenge for the synthesis of non-serendipitous species in order to study their magnetic behavior [47]. A variety of ligands containing $\mathrm{N}$ and $\mathrm{O}$ donor atoms have been employed for the preparation of such systems. Among such ligands are the Schiff bases [8-13].

The Schiff base compounds constitute an important class of ligands which have been extensively studied in coordination chemistry, mainly due to their facile synthesis and easily tunable steric, electronic and catalytic properties. Schiff bases having donors such as $\mathrm{N}_{2} \mathrm{O}_{2}$ and $\mathrm{N}_{4}$ around the metal ion form complexes of chromium, manganese, nickel and rhenium have been used as catalysts for carbonylation, hydrogenation, hydroformulation and expoxidation reactions [14-17]. Also, $\mathrm{N}_{2} \mathrm{O}_{2}$ donor Schiff bases and for their role in biological systems $[18,19]$ have been extensively studied as oxygen carriers and as catalysts for water splitting system [ 20-23]

In the present work, we report the preparation and characterization of a new type of homo- and hetero-trinuclear complexes formed by the reactions of cobalt(II), nickel(II) and copper(II) salts with the Schiff base ligand bis (vanillidene)malonylhydrazide derived from the condensation of vanillin and malonyldihydrazide. 


\section{EXPERIMENTAL}

\section{Materials and Methods}

The chemicals used throughout this work were all of Analar grade used as supplied without further purification. The di-acid hydrazide, malonyldihydrazide was prepared by the reaction of hydrazine hydrate with diethylmalonate 2:1 ratio, according to standard procedure [25]. The Schiff base ligand, bis (vanillidene) malonylhydrazide $\left(\mathrm{VMH}_{4}\right)$, was prepared by the condensation of $1: 2$ ratio of malonyldihydrazide $(0.01$ mol, $1.32 \mathrm{~g})$ and vanillin $(0.02 \mathrm{~mol}, 3.04 \mathrm{~g})$ in ethanol. The reaction mixture was refluxed for about 6 hours. Pale yellow precipitate result which was filtered off washed with cold ethanol and dried. The product was characterized by elemental analysis:

$\mathrm{MP}=138^{\circ} \mathrm{C}$

Found: C, 57.30; H, 5.23; N, 14.26\%

$\mathrm{C}_{21} \mathrm{H}_{20} \mathrm{~N}_{4} \mathrm{O}_{6}$ requires: C, 57.00; H, 5.00; N, $14.00 \%$

\section{Preparation of the complexes}

Throughout all the preparations 3:2 metal to ligand ratio was always used.

1- Complexes formed in neutral medium: To a solution of the ligand made by dissolving $0.01 \mathrm{~mol}$ in $30 \mathrm{ml}$ ethanol a solution of the metal salt containing $0.015 \mathrm{~mol}$ in $30 \mathrm{ml}$ ethanol was added. The mixture was refluxed on a water bath for 2-3 hours. After cooling, the precipitated complexes were filtered off, washed with ethanol and dried in vacuum desiccators.

2- Complexes formed in alkaline medium: An ethanolic solution of the ligand $(0.01 \mathrm{~mol}$ in $30 \mathrm{ml}$ ethanol) was made alkaline by the addition of $0.1 \mathrm{~N} \mathrm{KOH}$, then a solution containing $0.015 \mathrm{~mol}$ of the metal salt in $30 \mathrm{ml}$ ethanol was added slowly within 30 minutes. An excess of $\mathrm{KOH}$ (few drops) was added to the mixture until complete precipitation. The mixture was then digested on a water bath for about 10 minutes and left to cool. The separated complexes were filtered off, washed with ethanol and dried in vacuum desiccators.

\section{Analyses and physical measurements}

The ligand and its complexes were analyzed for carbon, hydrogen and nitrogen by using Perkin-Elmer 2400 analyzer at the School of Chemistry, University of Birmingham-UK, while cobalt, nickel and copper measured gravimetrically using standard methods [26]. Conductivity measurements were carried out on 10-3 M solutions in dimethylformamide (DMF) using LF-42 digital conductivity meter at room temperature. Infrared absorption spectra were recorded on recorded on IR-300 and Pye-Unicam SP-1100 infrared spectrophotometers on the 
range of $400-4000 \mathrm{~cm}^{-1}$ using $\mathrm{KBr}$ discs, at the College of Science, University of Salahaldean- Erbil. The measurements were performed on the sample in the form of $\mathrm{KBr}$ discs. The electronic spectra were recorded on a Shimadzu UV-Vis 160 A spectrophotometer for $10^{-3} \mathrm{M}$ solutions in dimethylformamide at room temperature, using $1 \mathrm{~cm}$ quartz cell. Melting points were measured by using Gallenkamp melting point apparatus at the range 0 to $350{ }^{\circ} \mathrm{C}$. The magnetic susceptibility measurements were made by the Faraday method at $25{ }^{\circ} \mathrm{C}$ using a Bruker BM6 instruments. Diamagnetic corrections were calculated using Pascal's constants [27].

\section{Determination of stability constant}

The conditional stability constants of some of the complexes were estimated spectrophotometrically by the following method: solutions containing exactly 3:2 proportion of the metal salt to the ligand were prepared. Then the low absorbance (Es) of these solutions was measured. Similar solutions were then prepared containing the same amount of the metal salt, but with excess ligand. In this case it was assumed that the complex is largely associated and consequently it had a higher absorbance (Em). The difference between the absorbance represented a measure of the degree of dissociation $(\alpha)$ of the complex [28] which given by

$\alpha=$ Em-Es $/$ Em

The stability constants $(\mathrm{K})$ were calculated by using the following equation:

$\mathrm{K}=1-\alpha / 4 \alpha^{3} \mathrm{C}^{2}$ (where $\mathrm{C}$ represent the concentration).

\section{Results and Discussion}

The following equations explain the reactions of the metal salts with the ligand and showing the formation of the complexes in both neutral and alkaline medium.

1- Neutral medium reactions:

$3 \mathrm{MX}_{2} \cdot \mathrm{nH}_{2} \mathrm{O}+2 \mathrm{VMH}_{4} \longrightarrow\left[\mathrm{M}_{3}\left(\mathrm{VMH}_{4}\right)_{2} \mathrm{X}_{6}\right]+3 \mathrm{nH}_{2} \mathrm{O}$

$2 \mathrm{MX}_{2} \cdot \mathrm{nH}_{2} \mathrm{O}+\mathrm{M}^{\prime} \mathrm{X}_{2} \cdot \mathrm{mH}_{2} \mathrm{O}+2 \mathrm{VMH}_{4} \longrightarrow\left[\mathrm{M}_{2} \mathrm{M}^{\prime}\left(\mathrm{VMH}_{4}\right)_{2} \mathrm{X}_{6}\right]$$$
\mathrm{MX}_{2} \cdot \mathrm{nH}_{2} \mathrm{O}+\mathrm{M}^{\prime} \mathrm{X}_{2} \cdot \mathrm{mH}_{2} \mathrm{O}+\mathrm{M}^{\prime \prime} \mathrm{X}_{2} \cdot \mathrm{yH}_{2} \mathrm{O}+2 \mathrm{VMH}_{4} \longrightarrow
$$

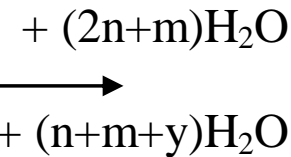

2- $\quad$ Alkaline medium complexes:

$$
\begin{aligned}
& 3 \mathrm{MX}_{2} \cdot \mathrm{nH}_{2} \mathrm{O}+2 \mathrm{VMH}_{4}+8 \mathrm{KOH} \longrightarrow \mathrm{K}_{2}\left[\mathrm{M}_{3}(\mathrm{VM})_{2}\right]+6 \mathrm{KX} \\
& 2 \mathrm{MX}_{2} \cdot \mathrm{nH}_{2} \mathrm{O}+\mathrm{M}^{\prime} \mathrm{X}_{2} \cdot \mathrm{mH}_{2} \mathrm{O}+2 \mathrm{VMH}_{4}+8 \mathrm{KOH} \longrightarrow \\
& \mathrm{K}_{2}\left[\mathrm{M}_{2} \mathrm{M}^{\prime}(\mathrm{VM})_{2}\right]+6 \mathrm{KX}+(8+2 \mathrm{n}+\mathrm{m}) \mathrm{H}_{2} \mathrm{O} \\
& \mathrm{MX}_{2} \cdot \mathrm{nH}_{2} \mathrm{O}+\mathrm{M}^{\prime} \mathrm{X}_{2} \cdot \mathrm{mH}_{2} \mathrm{O}+\mathrm{M}^{\prime \prime} \mathrm{X}_{2} \cdot \mathrm{yH}_{2} \mathrm{O}+2 \mathrm{VMH}_{4}+8 \mathrm{KOH} \longrightarrow \\
& \mathrm{K}_{2}\left[\mathrm{MM}^{\prime} \mathrm{M}^{\prime \prime}(\mathrm{VM})_{2}\right]+6 \mathrm{KX}+(8+\mathrm{n}+\mathrm{m}+\mathrm{y}) \mathrm{H}_{2} \mathrm{O}
\end{aligned}
$$


Where $\mathrm{M}, \mathrm{M}^{\prime}, \mathrm{M}^{\prime \prime}$ are the dipositive ions of cobalt, nickel and copper, respectively, $\mathrm{VMH}_{4}, \mathrm{VM}$ are the neutral and tetra basic forms of the ligand, $\mathrm{X}=\mathrm{Cl}^{-}$or $\mathrm{NO}_{3}{ }^{-}$and $\mathrm{n}, \mathrm{m}=6, \mathrm{y}=2,3$.

As indicated in the above equations, neutral complexes resulted from neutral medium, while anionic species obtained from alkaline medium reactions. In all cases 3:2 metals to ligand proportion was found and confirmed by the different studies conducted on these complexes, as shown by the analytical data given in Table 1 . All the complexes are stable in dry air at room temperature and have relatively high melting or decomposition points (above $350{ }^{\circ} \mathrm{C}$ ). They are insoluble in water, cold ethanol and methanol but they are slightly soluble in dimethylformamide (DMF). The low molar conductance for the neutral complexes in this solvent indicate their non-ionic nature, while the conductance values for the basic medium species suggested 2:1 electrolytic nature [29], Table 1. The stability constants were studied only for the neutral complexes but the other type precipitated on addition of alkali and thus prevents the measurements. The values shown in Table 1 reflect the similar stability of these complexes which most probably due to the same environments for all of them.

The coordination sites were concluded by comparison of the infrared absorption spectra of the ligand and its complexes, Table 2 . The band due to $\mathrm{C}=\mathrm{O}$ stretching mode lowered in neutral complexes by about 18-35 $\mathrm{cm}^{-1}$ and disappeared in anionic complexes due to deprotonation of the enol form of the ligand. This was confirmed by the disappearance of the $\mathrm{N}-\mathrm{H}$ bands due to the following tautomerism:

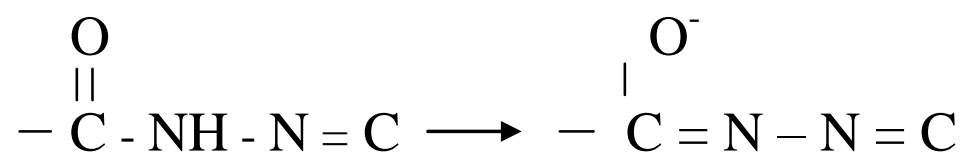

These observations suggested coordination through both carbonyl oxygen atoms for the neutral complexes [30,31] and enolic oxygen atoms for the anionic complexes [32,33]. In both types of complexes the azomethine $(\mathrm{C}=\mathrm{N})$ band lowered by about $15-30 \mathrm{~cm}^{-1}$ suggesting coordination through both azomethine nitrogen atoms [34]. The $\mathrm{OH}$ bands lowered by about 55-100 $\mathrm{cm}^{-1}$ for neutral complexes suggesting coordination through both hydroxyl oxygen atoms and disappeared for anionic complexes indicating that coordination took place through both phenoxy oxygen atoms, Table 2, [35, 36], since the C-O band which occurred in the ligand spectrum at $1210 \mathrm{~cm}^{-1}$ lowered in the spectra of these complexes by about $20 \mathrm{~cm}^{-1}$ and appeared around $1190 \mathrm{~cm}^{-1}$. Neutral complexes showed three bands due to $\mathrm{NO}_{3}$ groups $\left(v_{3}, v_{1}, v_{5}\right)$ at $995-1525 \mathrm{~cm}^{-1}$, Table 2 . The positions of these bands and the difference between the two bands of 
higher frequencies $\left(130-150 \mathrm{~cm}^{-1}\right)$ suggest monodentate action of nitrate groups in these complexes. Bands due to $\mathrm{Cl}$ ion could not be observed as such bands occur below $300 \mathrm{~cm}^{-1}$ which is out of our spectrophotometer range. For anionic complexes no band due to $\mathrm{NO}_{3}$ was found in their spectra which indicate the absence of $\mathrm{NO}_{3}$ groups from these complexes. This observation is in a good agreement with the conductance data and the suggested formulations. In addition, new bands were observed in the spectra of all complexes at about $420-430$ and $460-480 \mathrm{~cm}^{-1}$ and attributed to the stretching modes of M-O and M-N, respectively [36].

Table 3 gives the electronic spectral data and the suggested structures of the prepared complexes. The neutral hexa-coordinated cobalt and nickel complexes showed three bands in the visible region which attributed to high-spin octahedral symmetry. These bands due to the allowed transitions, ${ }^{4} \mathrm{~T}_{1 \mathrm{~g}}(\mathrm{~F}) \longrightarrow{ }^{4} \mathrm{~T}_{2 \mathrm{~g}}(\mathrm{~F})\left(v_{1}\right),{ }^{4} \mathrm{~T}_{1 \mathrm{~g}}(\mathrm{~F}) \longrightarrow{ }^{4} \mathrm{~A}_{2 \mathrm{~g}}(\mathrm{~F})\left(v_{2}\right)$, ${ }^{4} \mathrm{~T}_{1 \mathrm{~g}}(\mathrm{~F}) \longrightarrow{ }^{4} \mathrm{~T}_{1 \mathrm{~g}}(\mathrm{P})\left(v_{3}\right) \quad$ and $\quad{ }^{3} \mathrm{~A}_{2 \mathrm{~g}}(\mathrm{~F}) \longrightarrow{ }^{3} \mathrm{~T}_{2 \mathrm{~g}}(\mathrm{~F})\left(v_{1}\right)$, ${ }^{3} \mathrm{~A}_{2 \mathrm{~g}}(\mathrm{~F}) \longrightarrow{ }^{3} \mathrm{~T}_{1 \mathrm{~g}}(\mathrm{~F})\left(\mathrm{v}_{2}\right),{ }^{3} \mathrm{~A}_{2 \mathrm{~g}}(\mathrm{~F}) \longrightarrow{ }^{3} \mathrm{~T}_{1 \mathrm{~g}}(\mathrm{P})\left(\mathrm{v}_{3}\right)$ for cobalt and nickel complexes, respectively. For the hexa- coordinated copper complexes only one band was observed (Table 3 ) and attributed to the three combined transitions ${ }^{2} \mathrm{~B}_{1 \mathrm{~g}} \longrightarrow{ }^{2} \mathrm{~A}_{1 \mathrm{~g}},{ }^{2} \mathrm{~B}_{1 \mathrm{~g}} \longrightarrow{ }^{2} \mathrm{~B}_{2 \mathrm{~g}},{ }^{2} \mathrm{~B}_{1 \mathrm{~g}} \longrightarrow{ }^{2} \mathrm{E}_{\mathrm{g}}$. Since this band is broad, asymmetrical and below $1500 \mathrm{~cm}^{-1}$, therefore distorted (Jhan-Teller distortion) octahedral structure was suggested [37].

For the neutral mixed metal complexes that contain both cobalt and nickel, three bands were also observed for each metal ion and attributed to octahedral structure. For the mixed metal complexes of cobalt or nickel with copper, four d-d bands were observed in their spectra, three of them due to the allowed transitions for cobalt or nickel and the fourth one due to the allowed transition for copper ion. Figure I represent the electronic spectrum for the complex $\left[\mathrm{Co}_{2} \mathrm{Cu}\left(\mathrm{VMH}_{4}\right)_{2}(\mathrm{NO} 3)_{6}\right]$ as an example for the spectra of such compounds. The electronic spectra of the mixed metal complexes containing cobalt, nickel and copper ions were also studied. Such spectra are very complicated as seven bands were expected but some of them are located at nearly the same region. The calculated ratio of $v_{2} / v_{1}$ for cobalt complexes (1.32-1.35) and for nickel complexes (1.541.63) confirms the octahedral structure [38]. The low value of $\beta(0.28$ 0.33 ) for cobalt complexes refer to the high proportion of covalence, while the higher value $(0.72-0.78)$ for nickel complexes indicates the low covalent character, Table 3, [39]. In the spectra of the anionic species only one band was observed for cobalt, nickel and copper complexes, located at $13945-14822 \mathrm{~cm}^{-1}$ for cobalt and at $13184-13600 \mathrm{~cm}^{-1}$ for nickel complexes. This band is due to ${ }^{4} \mathrm{~A}_{2}(\mathrm{~F}) \longrightarrow{ }^{4} \mathrm{~T}_{1}(\mathrm{P})\left(v_{3}\right)$ and ${ }^{3} \mathrm{~T}_{1}(\mathrm{~F}) \longrightarrow{ }^{3} \mathrm{~T}_{1}(\mathrm{P})\left(\mathrm{v}_{3}\right)$ transitions in tetrahedral field. The other two bands, $v_{1}$ and $v_{2}$, are located at the lower part of the spectra, therefore could not be observed due to the instrument limitation. Figure II shows 
the spectrum of $\mathrm{K}_{2}\left[\mathrm{Co}_{2} \mathrm{Ni}(\mathrm{VM})_{2}\right]$ were two bands appeared, one for cobalt and the other for nickel, representing $v_{3}$ for each ion. Again, one band for anionic copper complexes was appeared in the region around $19157-19410 \mathrm{~cm}^{-1}$. This band is due to the two combined transitions ${ }^{2} \mathrm{~B}_{1 \mathrm{~g}} \longrightarrow{ }^{2} \mathrm{~A}_{1 \mathrm{~g}}$ and ${ }^{2} \mathrm{~B}_{1 \mathrm{~g}} \longrightarrow{ }^{2} \mathrm{E}_{\mathrm{g}}$, therefore square planar structure was suggested for these tetracoordinated complexes.

The presence of charge transfer bands are due to $\pi-\pi^{*}$ transition and observed for all the complexes. These bands indicate the presence of certain amount of $\pi$-bonding that due to the back donation as the ligand contains empty $\pi^{*}$-orbital. The values of CFSE are ranging between 925812456, 11900-12456 and 7936-8536 $\mathrm{cm}^{-1}$ for cobalt, nickel and copper complexes in octahedral field, respectively, indicating that nickel complexes have the highest stabilization energy and copper complexes have the lowest values.

The magnetic moments for all the complexes are given in Table 2 . The values for cobalt complexes (4.19-4.48 BM) are in good agreement with that expected for high-spin octahedral and tetrahedral environments for cobalt(II), $\mathrm{d}^{7}$-system indicating the presence of three unpaired electrons. The values of the magnetic moments for hexa-coordinated and tetra-coordinated nickel(II) complexes (2.39-2.98 BM), Table 2, indicate the presence of two unpaired electrons (high-spin $\mathrm{d}^{8}$-system) and thus, confirming the tetrahedral structure for the tetra-coordinated $\mathrm{Ni}$ (II) complexes. The relatively low values of the magnetic moments for cobalt and nickel complexes are probably due to antiferromagnetism resulting from the interaction of the adjacent metallic centers, known as the super exchange mechanism [40]. In case of copper(II) complexes the values of the magnetic moments $(2.42-2.46 \mathrm{BM})$ are corresponding to the presence of one unpaired electron $\left(\mathrm{d}^{9}\right.$-system). The little high values are expected to be due to orbital contributions and/or, in some cases to super exchange mechanism either through the interaction of $\mathrm{Cu}^{+2} \ldots . . \mathrm{Cu}^{+2}$ or by the involvement of the ligand causing ferromagnetic behavior [41, 42]. The values magnetic moments agreed well with the proposed structures and the number and positions of the electronic spectral bands observed in the visible region for these complexes [38].

For all the other complexes containing more than one metal ion, the values of the magnetic moments agreed well with the high-spin character which represents the resultant of the individual moment for each ion. In all cases the values are lower than would be expected which is due as mentioned above, to the antiferromagnetic behavior.

The nature of the complexes and the stability constant (ranging between $1.09 \times 10^{4}-1.79 \times 10^{4}$ ) for some of those prepared in neutral medium were studied in solution (the study can not be conducted for the anionic complexes since they are precipitated upon addition of alkali). 1:1 metal to ligand ratio was obtained and all the species have similar 
stability constants as the environmental factors surrounding the metal ions are nearly the same. Since all the complexes are high-spin, therefore, the effects of CFSE on the stability constants are the same for all the complexes.

\section{Conclusion}

From the different studies conducted on the ligand and its complexes and from the given data, the following conclusion can be drawn: The ligand acts as hexa-dentate in both neutral and basic media (Figures III and IV). High-spin octahedral complexes obtained from neutral solution, while tetra-coordinated complexes with tetrahedral structure for cobalt and nickel complexes and square planar structure for copper complexes resulted from alkaline solution. The study of the nature of the complexes in solution showed the formation of only 1:1 mononuclear species. This is occurred due to the weak HO - M bonding which couldn't stabilize the trinuclear framework in solution in comparison to the solid state.

\section{REFERENCES}

1) D. Gattaeschi and R. Sessoli, Science, 265, 1054 (1994).

2) A. L. Bara, A.Caneschi, R. Sessoli and L. Sorace, J. Am. Chem. Soc., 1215302 (1999).

3) T. J. Hebden, W.W. Brennessel and P. L. Holland, J. Chem. Soc., Dalton Trans, 32, 3855 (2006).

4) J. Terceno, C. R. Bas, J. Mahia and A. Maestro, Inorg. Chem., 41, 5373 (2002).

5) J. Terceno, C. Diaz and M. Maestro, Inorg. Chem., 41, 6780 (2002).

6) M. Fondo, M. Garcia, J. Sanmartin and A. L. Lamas-Saiz, J. Chem. Soc., Dalton Trans, 35, 4260 (2006).

7) H. Kumagai, C. J. Kepent and M. Kurmoo, Inorg. Chem., 41, 3410 (2002).

8) P. G. Cozzi, Chem. Soc. Rev., 33, 410 (2004).

9) P. H. Aubert, P. Auderbert and M. Maumy, Chem. Mater, 13, 2223 (2001).

10) O.Prakash and A. Kumar, Molecules, 11, 43 (2006).

11) D. J. de Geest, A.Noble, B. Moubaraki, K. S. Murray and S. Broker, J. Chem. Soc., Dalton Trans, 4, 467 (2007).

12) H. Hsieh, Ya. Kuo and H. Gau, J. Chem. Soc., Dalton Trans, 14, 2428 (2005).

13) J. M. Tanski, B. V. Kelly and G. Parkin, J. Chem. Soc., Dalton Trans, 14, 2442 (2005).

14) E. Dunach, A. P. Esterves and S. Olevero, J. Electro. Anal. Chem., 39, 566 (2004).

15) E. G. Samsel and J. K. Kochi, J. Am. Chem. Soc., 107, 7606 (1985). 
16) M. Weitzer and S. Brooker, J. Chem. Soc., Dalton Trans, 14, 2428 (2005).

17) S. Naskar, D. Mishra, M. Corbella and A. J. Blake, J. Chem. Soc., Dalton Trans 14, 2448 (2005).

18) M. R. Bermejo, A. Castineiras and R. L. Beddose, J. Chem. Soc., Dalton Trans, 1337 (1999).

19) M. Watkinson, M. Fondo, M. R. Bermejo and M. Naeem, J. Chem. Soc., Dalton Trans, 31 (1999).

20) M. Ramesh, K. B. Chandraseker and K. H. Reddy, Indian J. Chem., 39 A, 1337 (2000).

21) A. Anthony and S. Balasubramanian, Inorg. Chem. Comm. 10, 908 (2005).

22) I. J. Sallomi and A. J. Al-Shaheen, Transition Met. Chem. 19, 275 (1994); Polyhedron, 17, 1429 (1998); I. J. Sallomi, A. A. Abdul Rahman and T. H. mahmood, Mu'tah, Lil-Buhuth Wad-Dirasat, 18, 95 (2003).

23) I. J. Sallomi, A. Al-Obaydi and Z. F. Dawood, J. Educ. Sci., 50, 62 (2001).

24) I. J. Sallomi and R. A. E. Hadad, J. Educ. Sci., 16, 110 (2004).

25) W. Baker, C. N. Hasker and J. F. W. McOmine, J. Chem. Soc., 170 (1950).

26) A. I. Vogel "A text book of quantitative inorganic analysis" $3^{\text {rd }}$. ed.John Wiley, New York (1971).

27) P. W. Selwood, "Magneto chemistry" Interscience, New York (1956).

28) A. E. Harvey and D. L. Manning, J. Am. Chem. Soc., 72, 4488 (1952).

29) W. J. Geary, Coord. Chem. Rev., 7, 81 (1971).

30) K.dey and K.C.Ray;Inorg.Chim.Acta,10,139.(1974).

31) R.C.Aggarwal and K.K.Narang,Inorg,Chim.Acta,12,651(1973).

32) I.J.Sallomi \& A. J. Al-Shaheen, Transition Met. Chem. 19, 275 (1994).

33) W. S. Lindsay, J. Chem. Soc., 1382 (1958).

34) K. Dey, S. Ray. P. K. Battacharya, A. Gangopadhyag, K. K. Bhasin and R. D. Vema, J.Indian Chem.Soc.,62,809(1985).

35) M.A.M.Al-Tayy, Ph.D. Thesis, University of Mosul, Mosul Iraq (1996).

36) K. Nakamoto "Infrared specra of inorganic and coordination compounds", $5^{\text {th }}$.ed. Part B, Wiley-Interscince, New York, (1997).

37) E.J.Duff, M.N. Hughes and K.J.ut,J,Chem.Soc.,57,363(1969)..

38) M.P. Teotia, D.K.Rastogi and W.U. Malik, Inorg. Chim. Acta, 7, 39, (1973).

39) A.B.P. Lever, Electronic spectra of some transition metal complexes, J. Chem. Edu., 45,711(1968).

40) A.Kumar and L.K.Mishan,J.Indan.Chem.Soc.,66,268(1989).

41) Z. K. Chan, C. H. Lin, C. C. Wang, J. C. Wang and C. w. Liu, J. Chem. Soc., Dalton Trans, 2183 (2008).

42) J. J. Fawali, S. Rane, K. Boukheddaden and P. Bakare, Indian J. Chem. 43 A, 2563 (2004). 
Some New Trinuclear Vanillin Schiff Base Complexes of Cobalt, Nickel and ...

Table 1- Analytical data and some physical properties

\begin{tabular}{|c|c|c|c|c|c|c|c|c|c|}
\hline \multirow{2}{*}{ Compound } & \multirow{2}{*}{$\begin{array}{l}\Omega_{\mathrm{M}} \\
\mathrm{cm}^{2} \\
\mathrm{ohm}^{-} \\
\mathrm{mol}_{\text {in DMF }}^{-}\end{array}$} & \multirow{2}{*}{ Colour } & \multirow{2}{*}{$\begin{array}{l}\text { MP } \\
\mathbf{C}^{\circ}\end{array}$} & \multirow{2}{*}{$\begin{array}{l}\mu_{\text {eff }} \\
(\mathbf{B M})\end{array}$} & \multicolumn{5}{|c|}{ Analysis \%, Found (Calculated) } \\
\hline & & & & & $\mathbf{C}$ & $\mathbf{H}$ & $\mathbf{N}$ & $\mathbf{M}$ & $\mathbf{C l}$ \\
\hline $1-\left[\mathrm{Co}_{3}\left(\mathrm{VMH}_{4}\right)_{2}\left(\mathrm{NO}_{3}\right)_{6}\right]$ & 37 & $\begin{array}{l}\text { Pale } \\
\text { yellow }\end{array}$ & 230 & 4.19 & $\begin{array}{l}33.68 \\
(33.81) \\
\end{array}$ & $\begin{array}{l}3.12 \\
(2.97)\end{array}$ & $\begin{array}{l}14.68 \\
(14.53)\end{array}$ & $\begin{array}{l}13.16 \\
(13.10)\end{array}$ & \\
\hline $2-\left[\mathrm{Co}_{3}\left(\mathrm{VMH}_{4}\right)_{2} \mathrm{Cl}_{6}\right]$ & 25 & $\begin{array}{l}\text { Pale } \\
\text { brown }\end{array}$ & 231 & 4.48 & & & & $\begin{array}{l}14.50 \\
(14.85)\end{array}$ & $\begin{array}{l}\mathbf{1 7 . 6 0} \\
(\mathbf{1 7 . 8 8})\end{array}$ \\
\hline $3-\left[\mathrm{Ni}_{3}\left(\mathrm{VMH}_{4}\right)_{2}\left(\mathrm{NO}_{3}\right)_{6}\right]$ & 38 & $\begin{array}{l}\text { Pale } \\
\text { green }\end{array}$ & 208 & 2.39 & $\begin{array}{l}34.02 \\
(33.83)\end{array}$ & $\begin{array}{l}3.12 \\
(2.97)\end{array}$ & $\begin{array}{l}14.41 \\
(14.54)\end{array}$ & $\begin{array}{l}13.01 \\
(13.06)\end{array}$ & \\
\hline $4-\left[\mathrm{Ni}_{3}\left(\mathrm{VMH}_{4}\right)_{2} \mathrm{Cl}_{6}\right]$ & 40 & $\begin{array}{l}\text { deep } \\
\text { yellow }\end{array}$ & 242 & 2.92 & & & & $\begin{array}{l}14.62 \\
(14.86)\end{array}$ & $\begin{array}{l}\mathbf{1 7 . 7 1} \\
(\mathbf{1 7 . 8 9})\end{array}$ \\
\hline $5-\left[\mathrm{Cu}_{3}\left(\mathrm{VMH}_{4}\right)_{2}\left(\mathrm{NO}_{3}\right)_{6}\right]$ & 30 & $\begin{array}{l}\text { deep } \\
\text { yellow }\end{array}$ & 232 & 2.46 & $\begin{array}{l}\text { 33.61 } \\
(33.47)\end{array}$ & $\begin{array}{l}2.80 \\
(2.94)\end{array}$ & $\begin{array}{l}14.22 \\
(14.38)\end{array}$ & $\begin{array}{c}14.0 \\
(13.92)\end{array}$ & \\
\hline 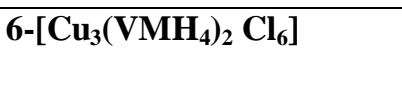 & 29 & $\begin{array}{l}\text { Pale } \\
\text { brown }\end{array}$ & 275 & 2.48 & & & & $\begin{array}{l}15.70 \\
(15.84)\end{array}$ & $\begin{array}{l}\mathbf{1 7 . 4 0} \\
(\mathbf{1 7 . 6 7 )}\end{array}$ \\
\hline $7-\left[\mathrm{Co}_{2} \mathrm{Ni}\left(\mathrm{VMH}_{4}\right)_{2}\left(\mathrm{NO}_{3}\right)_{6}\right]$ & 35 & $\begin{array}{l}\text { Pale } \\
\text { green }\end{array}$ & 276 & 3.53 & & & & $\begin{array}{l}\text { Co,8.69(8.33) } \\
\text { Ni,4.65(4.35) }\end{array}$ & \\
\hline $8-\left[\mathrm{Ni}_{2} \mathrm{Co}\left(\mathrm{VMH}_{4}\right)_{2}\left(\mathrm{NO}_{3}\right)_{6}\right]$ & 25 & $\begin{array}{l}\text { Pale } \\
\text { green }\end{array}$ & 270 & 2.98 & & & & $\begin{array}{l}\mathrm{Ni}, 8.69(8.73) \\
\mathrm{Co}, 4.56(4.35)\end{array}$ & \\
\hline $9-\left[\mathrm{Co}_{2} \mathrm{Cu}\left(\mathrm{VMH}_{4}\right)_{2}\left(\mathrm{NO}_{3}\right)_{6}\right]$ & 38 & $\begin{array}{l}\text { Pale } \\
\text { green }\end{array}$ & 266 & 3.23 & & & & $\begin{array}{l}\text { Co,8.40(8.64) } \\
\text { Cu,4.72(4.66) }\end{array}$ & \\
\hline $\begin{array}{l}10- \\
{\left[\mathrm{Cu}_{2} \mathrm{Ni}\left(\mathrm{VMH}_{4}\right)_{2}\left(\mathrm{NO}_{3}\right)_{6}\right]}\end{array}$ & 40 & $\begin{array}{l}\text { Pale } \\
\text { brown }\end{array}$ & 271 & 3.11 & & & & $\begin{array}{l}\mathrm{Cu}, 9.40(9.35) \\
\mathrm{Ni}, 4.31(4.32)\end{array}$ & \\
\hline $\begin{array}{l}11- \\
{\left[\mathrm{CoNiCu}\left(\mathrm{VMH}_{4}\right)_{2}\left(\mathrm{NO}_{3}\right)_{6}\right]}\end{array}$ & 34 & Yellow & 256 & 3.86 & & & & $\begin{array}{l}\text { Co,3.85(4.35) } \\
\text { Ni,4.51(4.35) } \\
\text { Cu,4.71(4.69) }\end{array}$ & \\
\hline $12-\mathrm{K}_{2}\left[\mathrm{Co}_{3}(\mathrm{VM})_{2}\right]$ & 150 & $\begin{array}{l}\text { dark } \\
\text { brown }\end{array}$ & 314 & 4.22 & & & & $\begin{array}{l}16.55 \\
(16.87)\end{array}$ & \\
\hline $13-\mathrm{K}_{2}\left[\mathrm{Ni}_{3}(\mathrm{VM})_{2}\right]$ & 140 & Brown & 310 & 2.98 & & & & $\begin{array}{c}16.75 \\
(16.87)\end{array}$ & \\
\hline $14-K_{2}\left[\mathrm{Cu}_{3}(\mathrm{VM})_{2}\right]$ & 139 & $\begin{array}{l}\text { dark } \\
\text { yellow }\end{array}$ & 320 & 2.42 & $\begin{array}{l}43.20 \\
(42.99)\end{array}$ & $\begin{array}{l}3.18 \\
(3.02)\end{array}$ & $\begin{array}{l}10.75 \\
(10.56)\end{array}$ & $\begin{array}{l}17.87 \\
(17.96)\end{array}$ & \\
\hline $15-\mathrm{K}_{2}\left[\mathrm{Co}_{2} \mathrm{Ni}(\mathrm{VM})_{2}\right]$ & 152 & $\begin{array}{l}\text { Yellowi } \\
\text { sh } \\
\text { green }\end{array}$ & 311 & 3.51 & & & & $\begin{array}{l}\text { Co,11.38(11.25) } \\
\text { Ni,5.51(5.60) }\end{array}$ & \\
\hline $16-\mathrm{K}_{2}\left[\mathrm{Ni}_{2} \mathrm{Co}(\mathrm{VM})_{2}\right]$ & 146 & $\begin{array}{l}\text { Yellowi } \\
\text { sh } \\
\text { green }\end{array}$ & 298 & 3.64 & & & & $\begin{array}{l}\text { Ni,11.29(11.21) } \\
\text { Co,5.72(5.62) }\end{array}$ & \\
\hline $17-\mathrm{K}_{2}\left[\mathrm{Co}_{2} \mathrm{Cu}(\mathrm{VM})_{2}\right]$ & 156 & $\begin{array}{l}\text { Dark } \\
\text { brown }\end{array}$ & 330 & 3.59 & & & & $\begin{array}{l}\text { Co,11.39(11.20) } \\
\text { Cu,6.15(6.04) }\end{array}$ & \\
\hline $18-\mathrm{K}_{2}\left[\mathrm{Cu}_{2} \mathrm{Ni}(\mathrm{VM})_{2}\right]$ & 140 & $\begin{array}{l}\text { Dark } \\
\text { brown }\end{array}$ & 286 & 3.12 & & & & $\begin{array}{l}\mathrm{Cu}, 12.41(12.03) \\
\text { Ni,5.62(5.55) }\end{array}$ & \\
\hline $19-\mathrm{K}_{2}\left[\mathrm{CoNiCu}(\mathrm{VM})_{2}\right]$ & 143 & Brown & 302 & 4.02 & & & & $\begin{array}{l}\text { Co,5.51(5.60) } \\
\text { Ni,5.70(5.58) } \\
\text { Cu,6.12(6.04) }\end{array}$ & \\
\hline
\end{tabular}


Issam J. Sallomi \& Wijdan A. Al-Zeadan

Table 2- Some important infrared spectral data $\left(\mathrm{cm}^{-1}\right)$. 
Some New Trinuclear Vanillin Schiff Base Complexes of Cobalt, Nickel and ...

Table 2- Some important infrared spectral data $\left(\mathrm{cm}^{-1}\right)$.

\begin{tabular}{|c|c|c|c|c|c|c|c|c|c|}
\hline Neutral compound & $\mathbf{V}_{(\mathbf{O H})}$ & $\mathbf{v}_{(\mathbf{N H})}$ & $\mathbf{v}_{(\mathrm{C}=\mathbf{O})}$ & $\mathbf{v}_{(\mathrm{C}=\mathrm{N})}$ & $\boldsymbol{\delta}_{(\mathrm{OH})}$ & $\begin{array}{c}\mathbf{v}_{(\mathrm{N}-} \\
\mathrm{N}) \\
\end{array}$ & $\begin{array}{c}\mathbf{v}_{(\mathbf{M}-} \\
\mathbf{N}) \\
\end{array}$ & $\begin{array}{c}\mathbf{v}_{(\mathbf{M}-} \\
\mathbf{O}) \\
\end{array}$ & $\mathbf{v}\left(\mathrm{NO}_{3}\right)$ \\
\hline $\mathrm{VMH}_{4}$ & 3480 & 3204 & 1660 & 1600 & 1290 & 998 & ---- & ---- & -------- \\
\hline$\left[\mathrm{Co}_{3}\left(\mathrm{VMH}_{4}\right)_{2}\left(\mathrm{NO}_{3}\right)_{6}\right]$ & 3400 & 3205 & 1640 & 1580 & 1260 & 1033 & 460 & 425 & $998,1385,1515$ \\
\hline$\left[\mathrm{Co}_{3}\left(\mathrm{VMH}_{4}\right)_{2} \mathrm{Cl}_{6}\right]$ & 3380 & 3200 & 1640 & 1585 & 1240 & 1034 & 470 & 420 & ------ \\
\hline$\left[\mathrm{Ni}_{3}\left(\mathrm{VMH}_{4}\right)_{2}\left(\mathrm{NO}_{3}\right)_{6}\right]$ & 3400 & 3210 & 1640 & 1580 & 1265 & 1034 & 470 & 420 & $1000,1385,1518$ \\
\hline$\left[\mathrm{Ni}_{3}\left(\mathrm{VMH}_{4}\right)_{2} \mathrm{Cl}_{6}\right]$ & 3400 & 3205 & 1640 & 1580 & 1270 & 1033 & 465 & 430 & -------- \\
\hline$\left[\mathrm{Cu}_{3}\left(\mathrm{VMH}_{4}\right)_{2}\left(\mathrm{NO}_{3}\right)_{6}\right]$ & 3400 & 3200 & 1640 & 1580 & 1265 & 1025 & 460 & 430 & $1000,1385,1518$ \\
\hline$\left[\mathrm{Cu}_{3}\left(\mathrm{VMH}_{4}\right)_{2} \mathrm{Cl}_{6}\right]$ & 3400 & 3200 & 1642 & 1580 & 1265 & 1025 & 470 & 430 & --------. \\
\hline$\left[\mathrm{Co}_{2} \mathrm{Ni}\left(\mathrm{VMH}_{4}\right)_{2}\left(\mathrm{NO}_{3}\right)_{6}\right]$ & 3400 & 3205 & 1635 & 1585 & 1260 & 1035 & 460 & 425 & $998,1385,1520$ \\
\hline$\left[\mathrm{Ni}_{2} \mathrm{Co}\left(\mathrm{VMH}_{4}\right)_{2}\left(\mathrm{NO}_{3}\right)_{6}\right]$ & 3405 & 3200 & 1640 & 1580 & 1265 & 1030 & 465 & 430 & $1000,1380,1518$ \\
\hline$\left[\mathrm{Co}_{2} \mathrm{Cu}\left(\mathrm{VMH}_{4}\right)_{2}\left(\mathrm{NO}_{3}\right)_{6}\right]$ & 3425 & 3220 & 1625 & 1570 & 1275 & 1030 & 480 & 430 & 998,1380,1515 \\
\hline$\left[\mathrm{Cu}_{2} \mathrm{Ni}\left(\mathrm{VMH}_{4}\right)_{2}\left(\mathrm{NO}_{3}\right)_{6}\right]$ & 3420 & 3205 & 1635 & 1570 & 1270 & 1033 & 470 & 420 & $998,1375,1525$ \\
\hline$\left[\mathrm{CoNiCu}\left(\mathrm{VMH}_{4}\right)_{2}\left(\mathrm{NO}_{3}\right)_{6}\right]$ & 3400 & 3205 & 1635 & 1570 & 1265 & 1025 & 460 & 425 & $1000,1380,1518$ \\
\hline Anionic complexes & $\mathbf{v}_{(\mathrm{C}=\mathrm{N})}$ & $\begin{array}{l}\text { v(azine) } \\
-\mathrm{C}=\mathrm{N}- \\
\mathrm{N}=\mathrm{C}-\end{array}$ & \multicolumn{2}{|c|}{$v_{(C-O)}$} & $\mathbf{v}_{(\mathrm{N}-\mathrm{N})}$ & \multicolumn{3}{|c|}{$\mathbf{v}_{(\mathbf{M}-\mathbf{N})}$} & $\mathbf{v}_{(\mathbf{M}-\mathbf{O})}$ \\
\hline $\mathrm{K}_{2}\left[\mathrm{Co}_{3}(\mathrm{VM})_{2}\right]$ & 1580 & 1585 & \multicolumn{2}{|c|}{1160} & 1025 & & 460 & & 425 \\
\hline $\mathrm{K}_{2}\left[\mathrm{Ni}_{3}(\mathrm{VM})_{2}\right]$ & 1580 & 1590 & \multicolumn{2}{|c|}{1160} & 1023 & & 470 & & 420 \\
\hline $\mathbf{K}_{2}\left[\mathrm{Cu}_{3}(\mathrm{VM})_{2}\right]$ & 1585 & 1595 & \multicolumn{2}{|c|}{1160} & 1025 & & 460 & & 425 \\
\hline $\mathrm{K}_{2}\left[\mathrm{Co}_{2} \mathrm{Ni}(\mathrm{VM})_{2}\right]$ & 1570 & 1588 & \multicolumn{2}{|c|}{1160} & 1030 & & 465 & & 425 \\
\hline $\mathrm{K}_{2}\left[\mathrm{Ni}_{2} \mathrm{Co}(\mathrm{VM})_{2}\right]$ & 1575 & 1590 & \multicolumn{2}{|c|}{1160} & 1030 & & 460 & & 425 \\
\hline $\mathrm{K}_{2}\left[\mathrm{Co}_{2} \mathrm{Cu}(\mathrm{VM})_{2}\right]$ & 1570 & 1585 & \multicolumn{2}{|c|}{1160} & 1030 & & 470 & & 425 \\
\hline $\mathrm{K}_{2}\left[\mathrm{Cu}_{2} \mathrm{Ni}(\mathrm{VM})_{2}\right]$ & 1585 & 1600 & \multicolumn{2}{|c|}{1160} & 1025 & & 460 & & 420 \\
\hline $\mathrm{K}_{2}\left[\mathrm{CoNiCu}(\mathrm{VM})_{2}\right]$ & 1580 & 1600 & \multicolumn{2}{|c|}{1160} & 1020 & & 460 & & 425 \\
\hline
\end{tabular}


Table 3- The electronical Spectral data for some of the complexes

\begin{tabular}{|c|c|c|c|c|c|c|c|c|c|}
\hline Compound & $v_{1}$ & $\mathbf{v}_{2}$ & $\mathbf{v}_{3}$ & C.T & $10 D_{q}$ & $\boldsymbol{\beta}$ & $\mathbf{v}_{2} / \mathbf{v}_{1}$ & CFSE & Structure \\
\hline$\left[\mathrm{Co}_{3}\left(\mathrm{VMH}_{4}\right)_{2}\left(\mathrm{NO}_{3}\right)_{6}\right]$ & 10730 & 14393 & 23364 & 33112 & 12634 & 0.337 & 1.34 & 10107 & Octahedral \\
\hline$\left[\mathrm{Co}_{2} \mathrm{Ni}\left(\mathrm{VMH}_{4}\right)_{2} \mathrm{Cl}_{6}\right]$ & $\begin{array}{l}10800 \\
10220 \\
\end{array}$ & $\begin{array}{l}14315 \\
16664 \\
\end{array}$ & $\begin{array}{l}23662 \\
26814 \\
\end{array}$ & $\begin{array}{l}31604 \\
32415 \\
\end{array}$ & $\begin{array}{l}12405 \\
10220 \\
\end{array}$ & $\begin{array}{l}0.312 \\
0.782 \\
\end{array}$ & $\begin{array}{l}1.32 \\
1.63 \\
\end{array}$ & $\begin{array}{l}10212 \\
11906 \\
\end{array}$ & $\begin{array}{l}\text { Octahedral } \\
\text { for Co \&Ni }\end{array}$ \\
\hline$\left[\mathrm{Ni}_{3}\left(\mathrm{VMH}_{4}\right)_{2}\left(\mathrm{NO}_{3}\right)_{6}\right]$ & 10037 & 16129 & 26315 & 35714 & 10037 & 0.758 & 1.61 & 12044 & Octahedral \\
\hline$\left[\mathrm{Cu}_{3}\left(\mathrm{VMH}_{4}\right)_{2} \mathrm{Cl}_{6}\right]$ & 13525 & ---- & ---- & 32110 & 13525 & --- & ---- & 81225 & Octahedral \\
\hline$\left[\mathrm{Co}_{2} \mathrm{Cu}\left(\mathrm{VMH}_{4}\right)_{2}\left(\mathrm{NO}_{3}\right)_{6}\right]$ & $\begin{array}{l}10650 \\
13227\end{array}$ & 14370 & 22222 & \begin{tabular}{|l|}
33988 \\
31152
\end{tabular} & $\begin{array}{l}11572 \\
13227\end{array}$ & 0.281 & 1.35 & $\begin{array}{l}9258 \\
7936\end{array}$ & $\begin{array}{l}\text { Octahedral } \\
\text { for Co\&Cu }\end{array}$ \\
\hline$\left[\mathrm{CoNiCu}\left(\mathrm{VMH}_{4}\right)_{2}\left(\mathrm{NO}_{3}\right)_{6}\right]$ & \begin{tabular}{|l|}
10380 \\
10630 \\
14306 \\
\end{tabular} & $\begin{array}{c}--- \\
16420 \\
--- \\
\end{array}$ & $\begin{array}{c}22138 \\
26460 \\
---- \\
\end{array}$ & \begin{tabular}{|l|}
31430 \\
34384 \\
30120 \\
\end{tabular} & \begin{tabular}{|l|}
12058 \\
10630 \\
14306 \\
\end{tabular} & $\begin{array}{l}--- \\
0.72 \\
---\end{array}$ & $\begin{array}{l}-- \\
1.54 \\
--- \\
\end{array}$ & $\begin{array}{c}--- \\
12456 \\
8536 \\
\end{array}$ & $\begin{array}{c}\text { Octahedral } \\
\text { for } \mathrm{Co}, \mathrm{Ni} \& \\
\mathrm{Cu}\end{array}$ \\
\hline $\mathrm{K}_{2}\left[\mathrm{Co}_{3}(\mathrm{VM})_{2}\right]$ & --- & --- & 13945 & 32635 & --- & --- & --- & --- & Tetrahedral \\
\hline $\mathrm{K}_{2}\left[\mathrm{Ni}_{3}(\mathrm{VM})_{2}\right]$ & ----- & ----- & 13333 & 32051 & ---- & ----- & ---- & ---- & Tetrahedral \\
\hline $\mathrm{K}_{2}\left[\mathrm{Co}_{2} \mathrm{Ni}(\mathrm{VM})_{2}\right]$ & ----- & --- & $\begin{array}{l}14822 \\
13184 \\
\end{array}$ & \begin{tabular}{|l|}
32051 \\
30816 \\
\end{tabular} & $\begin{array}{l}---- \\
--- \\
\end{array}$ & $\begin{array}{l}---- \\
--- \\
\end{array}$ & $\begin{array}{l}--- \\
--- \\
\end{array}$ & $\begin{array}{l}-- \\
--- \\
\end{array}$ & $\begin{array}{l}\text { Tetrahedral } \\
\text { for Co \& Ni }\end{array}$ \\
\hline $\mathbf{K}_{2}\left[\mathrm{Cu}_{3}(\mathrm{VM})_{2}\right]$ & 19410 & --- & --- & 32115 & 19410 & --- & --- & --- & Sq. Planar \\
\hline $\mathrm{K}_{2}\left[\mathrm{Co}_{2} \mathrm{Cu}(\mathrm{VM})_{2}\right]$ & $\begin{array}{c}-\cdots- \\
19157\end{array}$ & $-\cdot-$ & $\begin{array}{c}14534 \\
---\end{array}$ & $\begin{array}{l}32154 \\
30516\end{array}$ & --- & $--\cdot$ & $--\cdot$ & --- & $\begin{array}{l}\text { Co-Oct. } \\
\text { Cu-Sq. }\end{array}$ \\
\hline $\mathrm{K}_{2}\left[\mathrm{CoNiCu}(\mathrm{VM})_{2}\right]$ & $\begin{array}{c}---- \\
--- \\
19337 \\
\end{array}$ & $\begin{array}{l}--- \\
--- \\
-\cdots- \\
--\end{array}$ & $\begin{array}{c}14326 \\
13600 \\
---- \\
\end{array}$ & $\begin{array}{l}32020 \\
35460 \\
30416 \\
\end{array}$ & $\begin{array}{l}--- \\
--- \\
--- \\
\end{array}$ & $\begin{array}{l}--- \\
--- \\
-\cdots- \\
\end{array}$ & $\begin{array}{l}--- \\
--- \\
--- \\
\end{array}$ & $\begin{array}{l}--\cdot \\
--- \\
-\cdots\end{array}$ & $\begin{array}{c}\text { Co,Ni-Tet. } \\
\text { Cu-Sq. }\end{array}$ \\
\hline
\end{tabular}




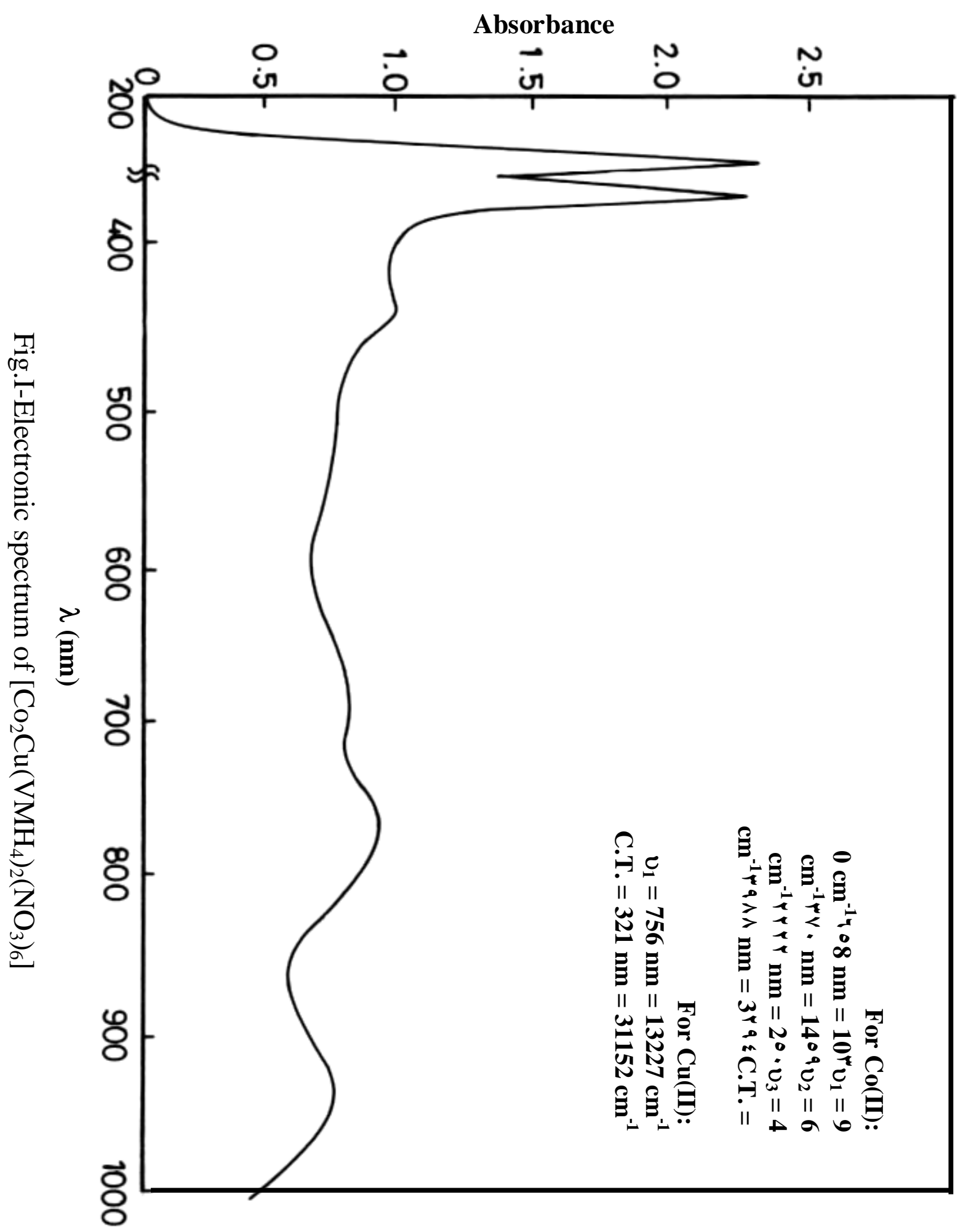




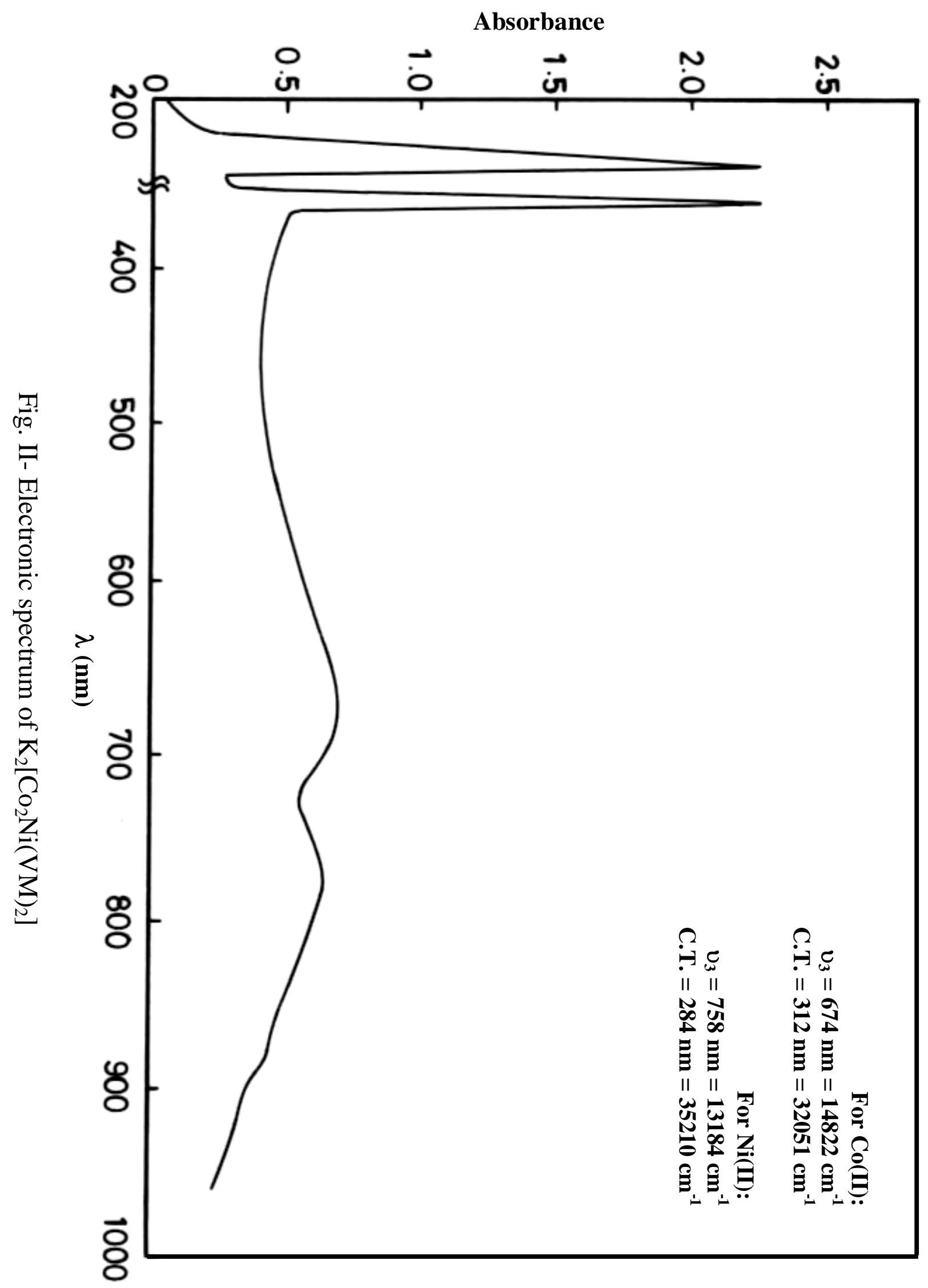




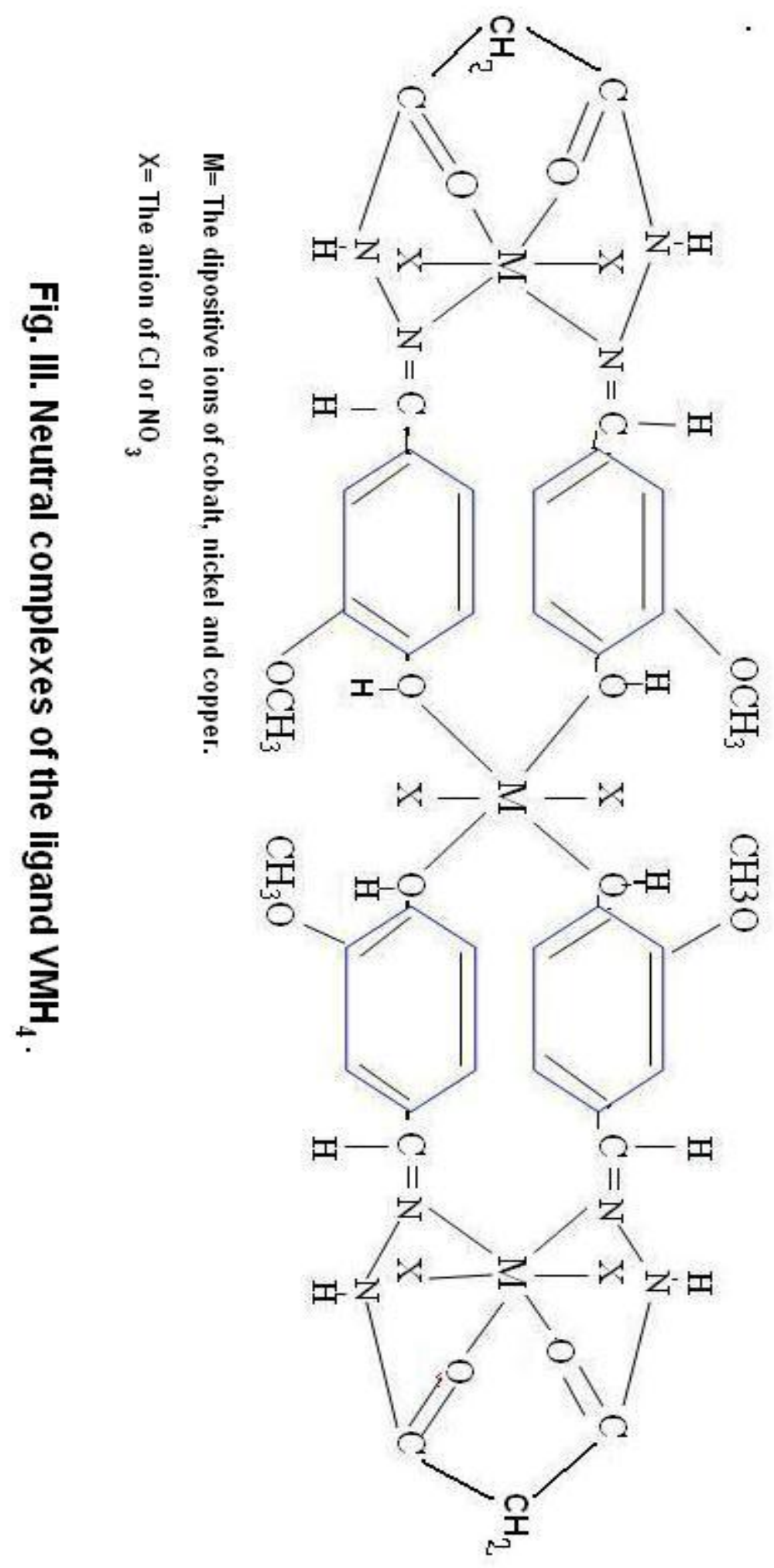



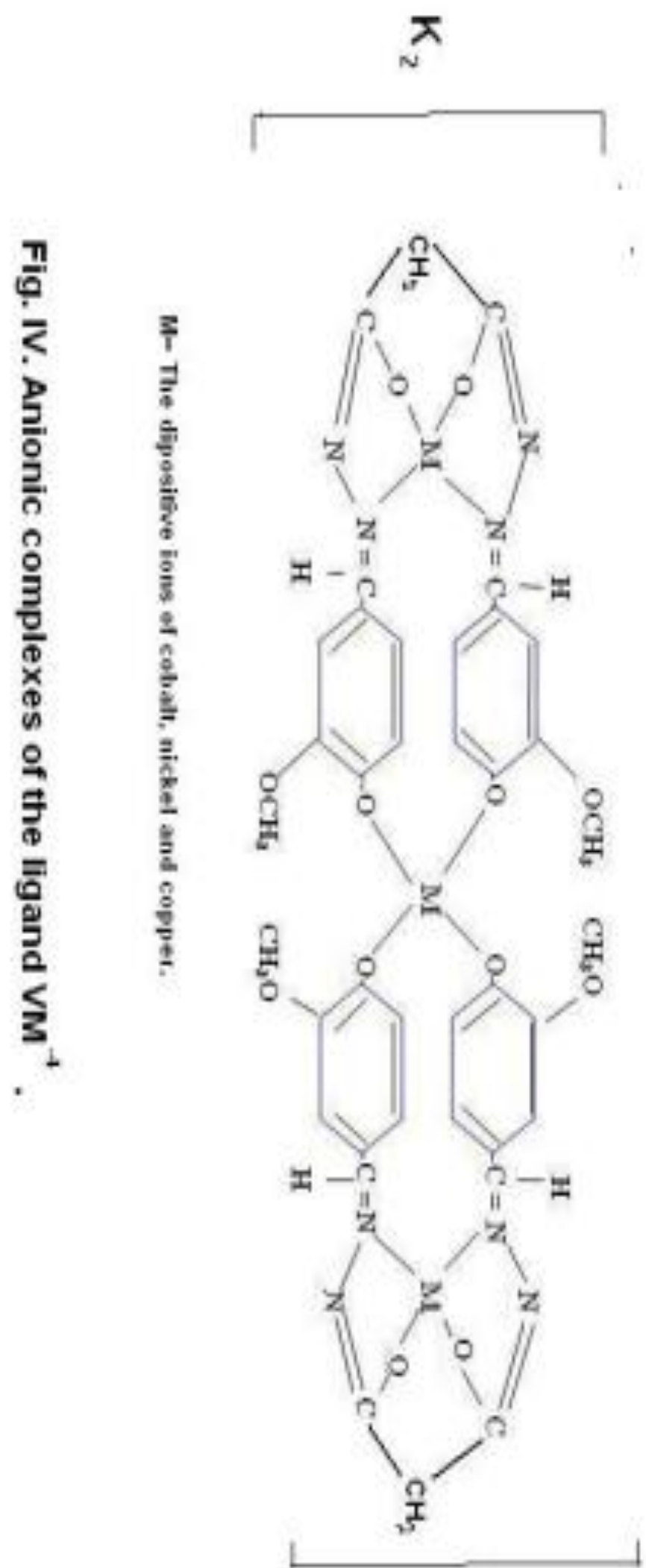